Jovana Lazarević

Faculty of Philology

University of Belgrade
UDC 316.74:81

DOI https://doi.org/10.18485/fid.2017.7.ch34

\title{
INTERRELATION BETWEEN CULTURE AND ENDANGERED LANGUAGES; THE EXAMPLE OF THE PHILIPPINES
}

Овај рад бави се односом између културе и угрожених језика, подржавајући ставове о неопходности очувања културне, језичке и биолошке разноврсности. Дефиниције угрожених језика и специфичан однос међу језицима који изумиру, образовни системи и могућа решења, представљени су у првом делу рада. У другом делу, разматрају се језичка, културна и биолошка разноликост, историјски развој истраживачких путања и тренутни ставови о овом питању. Трећи део рада бави се Casiguran Agta језиком, једним од тридесет угрожених језика на Филипинима, као примером како се губитак језичке разноликости одражава у губитку био-културне разноликости. Сва открића заснована су на постојећим теоријама и хипотезама; опасност од губитка био-културне и језичке разноврсности истакнута је како би се нагласио значај иницијатива које би требало да буду показане од стране говорника угрожених и мањинских језика.

Кључне речи: угрожени језици, био-културна разноврсност, језичка разноврсност, Casiguran Agta језик.

\section{Endangered languages}

A language is endangered "when its speakers cease to use it, use it in an increasingly reduced number of communicative domains, and cease to pass it on from one generation to the next" (McCarty, Skutnabb-Kangas and Magga according to UNESCO, 2003a:2)

McCarty et al. (2003a) define moribund languages as:

" (...) those which are no longer being learned by children; endangered languages as those which, though still being learned by children, will, if present trends continue, cease to be learned by children during the coming century, and safe languages as those which are neither moribund nor endangered."

Optimistic estimates are that the half of today's spoken languages will disappear or become seriously endangered by the end of the century. 
Other estimates include 95\% of today's spoken languages in this category. If the current situation continues, all the languages with less than 10,000 speakers will disappear, including those between 10,000 to 1 million speakers. If nothing changes in the future, the majority of disappearing languages will be indigenous languages, and the minority languages are not the exception to the ongoing trends, suggest McCarty, Skutnabb-Kangas and Magga (2008:98).

McCarty et al. (2008:298) consider our concern about endangered languages arguing that the number of speakers is already small, meaning that children require proficiency in one of the widely spoken languages in order to successfully climb the career ladder. But, apart from the current trends in the world, they come to the conclusion that this concern is justified explaining that the acquisition of the one of the widely spoken languages should not exclude or interfere with the acquisition of the mother tongue, because one is able to acquire multiple languages. So, why neglect this ability? They emphasize the importance of linguistic and cultural diversity as indicators of biodiversity concluding that language endangerment is a global question in which every world citizen takes part.

Chrystal (2000:32-66) also presents arguments on why we should care for dying languages explaining that linguistic diversity enriches human ecology and that languages stand for identity, preserve historical events and monuments, sum up human knowledge and themselves are an interesting subject.

McCarty et al. (2008:299) point out that:

"Language plays a key role in every human activity, thus language is affected by every effort to change power relations within any sociopolitical system. This is the starting point for understanding language and society. Because minority and indigenous languages are often viewed as obstacles to those in power, they are easily targets of attack".

They use the term linguistic genocide which according to them was the main aim of every colonial regime, and was followed by physical genocide and colonizing territory.

\section{The role of the educational system in language extinction}

McCarty et al. (2008:300) give various examples of the models of education which contributed to the language extinction, describing educa- 
tion policies for Native Americans, citing Craftword (1992:48): "The Us Commissioner for Indian Affairs in 1847 wrote that through sameness of language, the sameness of sentiment is produced and that barbarous dialects should be blotted out." They also list the similar models of education referring to Scandinavian case, in the example of Saami language: "All social sectors were involved in this national project, and children were punished for using their mother tongue."

\section{Current models of education}

McCarty et al. (2008:300) point out: "While schools alone cannot save endangered languages, schools can extinguish them within a few generations, almost on their own." They explain that using only the foreign language as the language of instruction severely influences the mother tongue, and results in considerably lower test performance, thus the opportunity for using mother tongue noticeably drops leading to the discontinuation in passing the mother tongue to further generations. Authors also warn that:"Abundant evidence exist that subtractive, submersion approaches, in which the dominant language is learned at the cost of mother tongue, can cause serious harm, and result in low school achievement, overrepresentation in underemployment, criminal, alcoholism, mental illness etc."

Skutnabb-Kangas (2009:3) gives the example of subtractive learning in the case of indigenous, minority and tribal students (with the exception of the Maori and Saami population) explaining that: "(..) they are being taught through the medium of dominant language, at least after first few grades, often from the start-provided that they attend school at all."

Magga, Nicolaisen et al. (2008:3) also stress the negative effects of subtractive learning:

"In subtractive language learning, a new dominant (majority) language is learned at the cost of the mother tongue which is displaced, leading to a diglossic situation, and later often replaced with the dominant language. Subtractive teaching subtracts from the child's linguistic repertoire, instead of adding to it. In this enforced language regime, the children undergoing subtractive education or at least their children are effectively transferred to the dominant group linguistically and culturally." 
Skutnab-Kangas (2009:2) brings into question freedom of choice, further discussing whether the education in dominant language is the students' (children's) choice, or the choice of their parents. She briefly explains why parents opt for the education in the dominant language, revealing the "logic" belying the freedom of choice. She explains:

"The thing that leads parents to such choices is glorification of the dominant language, and stigmatization of Indigenous/tribal/minority languages, they wish to shift languages and assimilate, through false promises of the benefits accrued. Without knowledge of the long-term consequences of subtractive learning, and without the adequate alternative, parents naively express their wish for the English/dominant language based education for their children, not realizing that the real choice was never offered to them."

\section{Preventing further language endangerment}

Skutnab-Kangas (2009:2) also gives the lists of the official documents and the review of the appropriate actions undertaken in order to preserve linguistic human rights, reminding us that language rights became more central only after the Second World War. The official documents confirming this are the 1948 Universal Declaration of Human Rights along with the International Covenant on Economic, Social and Cultural Rights and International Covenant on Civil and Human Rights (both from 1966), protecting individuals from language-based discrimination.

As for the grass-root language revitalization efforts, McCarty at al. (2008:303) use Maori (New Zealand) and Hawaiian (USA) language as the powerful examples. Those two languages got official language status along with English. These initiatives are the best example of the struggle for language rights. The authors also give a brief historical review stating that with the establishment of the Working Group on Indigenous Population in 1982, the drafting of a universal declaration on the rights of indigenous peoples began and that it was adopted in 2007. The International Labor Organization (ILO) in 1989 adopted the Indigenous and Tribal Peo-

ples Convention (no.169), and the decade 1995-2004 was proclaimed the decade of Indigenous peoples. Authors think that something can always be 
done even if the very small number of speakers of a language remained, and as a good example they state the Native American community who struggles for the revitalization of the language of their ancestors. Furthermore, they refer to the Green Book of Language Revitalization in Practice which provides concrete descriptions of language revitalization efforts.

McCarty et al. (2008:304) conclude that all languages have same potential and are equal, the mother tongue is central to all learning processes, and everyone should have right and opportunity to learn, to read in her/his own language. Whatever we do, our efforts will not save all the endangered languages in the world, but if there is a strong determination to maintain and develop a language, the success will surely follow.

\section{Linguistic, cultural and biological diversity}

Maffi (2005:600) gives the brief historical overview of the research trends concerning linguistic and bio-cultural diversity stating that 1980s might be remembered as the decade of biodiversity, 1990s as the decade of bio-cultural diversity, and the 2000s as the decade of bio-linguistic diversity, also known for the new field in science that deals with the relationship of biological, cultural and linguistic diversity. The main foci of this field are the relationship between language, traditional knowledge and the environment, studies and assessments of the common threats as well as the socio-cultural and environmental consequences of loss of these interlinked diversities. The importance of the maintenance and revitalization of biocultural diversity and the development of the related aspects of human rights are also pointed out.

The same author further observes the first parallels between evolutionary biology and historical linguistics and between languages and species referring to Charles Darwin. As for the links between language and environment, the history of anthropology is suggested. Linguistic anthropologists such as Boas, Sapir and Whorf, who were also "struck by the elaborate ways in which indigenous languages encoded and inventoried the characteristics of local landscape and its flora and fauna", contributed further to the development of concepts of linguistic and cultural relativity. Maffi (2005:200) also referring to Alfred Kroeber as one of the pioneers 
in North American anthropology, quotes Kroeber (1963:1) and states the following:

" (...) while it is true that cultures are rooted in nature, and can therefore never be understood except with reference to that piece of nature in which they occur (...), the immediate cause of cultural phenomena are other cultural phenomena (...) This does not prevent recognitions of relations between nature and culture, nor the importance of these relations to the full understanding of culture."

She suggests that this Kroeber's statement can be taken as an axiom in further research of the links between culture, language and nature.

\section{Current research}

Maffi (2005:601) explains:

"the recent interest in the links between language and the environment has arisen partly from the work carried out in past few decades by ethnobiologists and ethno-ecologists studying indigenous knowledge and use of local flora, fauna and ecosystems, as well as researchers interested in indigenous place naming."

The same author uses the term "linguistic ecologies" to further explain that the interest was partly rooted also in the linguistic research from the mid-1990s, illustrating this period as: "alarming and thought-provoking observation (...) ongoing and worldwide loss of biodiversity is paralleled by and seems interrelated to the extinction crisis affecting linguistic and cultural diversity." She explains that these observations contributed to the ongoing research and were shared by Krauss 1992; Harmon 1996; Posey 1997; Maffi 2001c and others.

To further illustrate the situation in which the indigenous peoples were, and which depended on many factors such as politics, economy and socio-economy she (2005:602) quotes (Harmon 1995, 1996 and Kraus 1996):

"It was increasingly apparent that the variety of cultural knowledge, beliefs and practices developed by human societies as well as the languages that embody them, are being placed at risk by the socioeconomic and political processes threatening the integrity and survival of indigenous 
and local cultures and environments in which they live-and that this rapid change has profound implications for the maintenance of life on earth. It became clear that interdisciplinary efforts were needed to bring together these different threads and begin to portray an integrated picture of the state of the diversity of life in all its forms-biological, cultural and linguistic-the pressure it is undergoing and the possible actions to insure its perpetuation."

Maffi (2005:602) takes the international working conference Endangered Languages, Endangered Knowledge, Endangered Environments as the great example of joined forces which brought together scientists in the linguistic, social, behavioral and natural fields as well as members of indigenous peoples in order to find the best approach for further theoretical research and practical solutions in the field of bio-cultural diversity. This led to the development of a new field oriented towards linguistics, cultural and biological diversity.

The same author further points out that our understanding of biodiversity and the complexity of this issue is not enough, nor is our ability to assess and measure it, and that without the appropriate actions we would most likely be the witnesses of "the demise of our bio-culturally rich world." This is why it is very relevant that research in the field influence policy and the public opinion on this matter. Several international organizations, both in the field of biodiversity conservation WWF, UNEP, IUCN, and in the field of cultural and linguistic diversity (UNESCO) have noted the significance of bio-cultural perspective and thus incorporated it in their own approaches and activities. Advances have also been made in the field of human rights, through the UN's Draft Declaration on the Rights of Indigenous Peoples as well as through other official documents that provide rights to the indigenous peoples, which is of the great importance to the protection and promotion of bio-cultural diversity.

Skutnabb-Kangas $(2008: 118)$ points out that states seem to see granting of human linguistic rights as something "divisive", which directly leads to "minorities reproducing themselves as minorities", and want cultural autonomy, economic autonomy, in the end political autonomy: their own state, and as a consequence, mother tongue based education for minorities is eventually seen as "leading to disintegration of nation states". 
Author concludes that these wrong beliefs are some of the important causes in linguistic genocide along with the lack of linguistic human rights in the education of minority and indigenous people.

Maffi (2005: 612) and Skutnabb-Kangas (2008:118) come to the same conclusion that most fundamental incentive for the protection and maintenance of bio-cultural diversity can come, not from "the top-down efforts", but only from "the ground-up actions" of indigenous and other societies around the world whose cultural identity, language and land are being threatened by global forces.

\section{Endangered languages in the Philippines}

\subsection{Negrito population}

Maffi (2006: 608) quotes Collard and Folley (2002:379) and states that :"(...) the cultural diversity is higher in tropical areas, as well as in Africa, North and South America, while it is lower in Europe." I will take one of the thirty endangered languages in Philippines referring to by Headland (2003) as an example in order to further illustrate and complement the aforementioned theoretical framework.

The official languages in Philippines are Filipino and English. As stated in the World Factbook, Central Intelligence Agency (2013) there are 19 recognized regional languages and those are: Aklanon, Bikol, Cebuano, Chavacano, Hiligaynon, Ibanag, Ilocano, Ivatan, Kapampangan, Kinaraya, Maguindano, Maranao, Pangasinan, Sambal, Surigaonon, Tagalog, TausugWaray-Waray, Yakan.

According to the National statistics office, the ethnic groups in Philippines are: $24.4 \%$ Tagalog, 21.4\% Visayan, 9.8\% Ilocano, 8.4\% Ilonggo, $6.8 \%$ Bicolano, 4\% Waray, and $26.1 \%$ other local, $0.1 \%$ other foreign groups.

According to Headland (2003:1) there are between 100 and 150 languages spoken in the Philippines today. A fourth of these languages- thirty two are spoken by Negrito populations . They are considered to be aborigines of the Philippines, because their ancestors migrated into these islands 20,000 years ago. During the Spanish conquest they constituted $10 \%$ of 
the Philippine population. They mainly lived by hunting, gathering and trading forest products with non-Negrito coastal people. The rest of the island inhabitants, 90\% were farmers, descendents of the early Austronesians, who began migrating into the Islands much later, around 5,000 years ago. Today the Negrito population numbers around 33,000 comprising only $0.05 \%$ of the overall national population. All of the thirty two Negrito groups speak endangered languages. Sixteen of these groups live in the Sierra Madre Mountains, and each group speaks its own Austronesian language, which they call Agta.

\subsection{The Casiguran Agta population-Endangered bio-cultural diversity}

Headland (2003:2) describes the Casiguran Agta population, and the ways in which the change of their lifestyle influenced bio-cultural diversity in this area:

"(...) the Casiguran Agta population lives in the foothills and seacoast of the Sierra Madre, near the town Casiguran, Aurora province. They numbered 1,000 people in 1936, and 600 in the 1980s, and this number has remained stationary since then. The Agta were hunters and gatherers, and they lived in the largest rainforest in the Philippines. Today many things have changed. Only 3\% of the old-growth tropical forest remains, and the game and fish are almost extinct, as are most of the plants and trees typical of this area. Logging and mining companies, as well as Filipino farmer-settlers have taken over Agta lands, and in the northern $\mathrm{Au}-$ rora, they outnumbered the Casiguran Agta people 85:1. Instead of the living in the rainforest distant from Filipino lowland farming communities, since the 1990s, almost all Agta families have lived on or near the farming settlements where they worked as casual laborers for Tagalog lowlanders in exchange for rice, liquor, used clothing and money. This multilingual population today understands and speaks Tagalog, and since the road from Manila to Casiguran town was built in 1977, more and more Agta population leave for the capital city. (...) Commercial western medicines in town have replaced traditional plant medicines, Christianity has replaced animism, wild forest plants have disappeared, and traditional rice grains 
have been replaced with the new hybrid rice seed. The outside world has introduced new concepts and ideas that have changed the way Negritos think in Agta. (...) The traditional Agta culture is not only endangered, but moribund."

Based on these statements, we can conclude that not only has the Casiguran Agta ecosystem changed, but also the way of life in this area, which clearly indicates the decrease of bio-cultural diversity in this region. A complete bibliography of all scholarly references on the Agta people may be found at Headland and Griffin (1997).

\subsection{The Casiguran Agta language-endangered language}

Headland (2003:6) noted:

"The Casiguran Agta language is not endangered because it is moribund, but because Agta people today are surrounded or outnumbered 85:1 by 50,000 Tagalog speakers. Most Agta families now live next door to the Tagalog population instead of with each other. Until 1960s no Agta children attended school. Today they attend elementary schools for at least a year or two, but the education is in Tagalog language."

Here we can easily notice the negative side of subtractive learning, where the dominant language is learned at the cost of the mother tongue. Agta is still spoken at home, and it is still the mother tongue of Agta children, but as soon as children leave their homes they are engaged in interethnic relations with the Taglog population, in Tagalog language. The majority of terms from the fields of science, technology and politics are borrowed from Tagalog, because the Casiguran Agta population who have been forest oriented and hunting for millennia didn't have terms for contemporary phenomena in their own language.

Headland (2003:7) describes the richness of Casiguran Agta language explaining that verbs of this language can be paraphrased in hundreds of different ways by adding to the verb root various combinations of inflexional prefixes, suffixes and infixes, and as an example he states the following, "the Agta noun pana means arrow, this verb root can appear in hundred different ways e.g. nagpana-shot an arrow, pinana- shot him pinumana- shot at nothing in particular...etc. He explains that the Casigu- 
ran Agta language was so rich that it contained "603 terms for plant names, 127 terms for different types of fish, 44 terms for seashells, 14 for snails, 21 names for types of rattan...etc." Unfortunately, these semantic domain concepts are no longer important in the Agta culture because they are not needed and the Agta language is endangered because it is changing under the influence of Tagalog language, and more and more terms are borrowed from Tagalog, so that today's Agta language doesn't resemble the Agta language of the 1960s.

\section{Conclusion}

As Headland (2003) suggests, the loss of any language, and the loss of bio-cultural and linguistic diversity represent the great loss for humanity. In this paper you can find a brief overview of the theoretical framework along with the global initiatives which can and should prevent the loss of linguistic and bio-cultural diversity. This issue is important for each and every one of us, because we never know when or if our culture and language could become extinct. As Maffi (2005:612) explains:

"Most fundamental impetus for the protection and maintenance of biocultural diversity can come, not from the top-down efforts, but only from the ground-up actions of indigenous and other societies worldwide whose cultural identity, language and land are being threatened by global forces."

Considering the ways in which culture and endangered languages are linked, as well as the different causal connections existing between them, it is of the utmost importance that policy and public opinion be influenced in due time so that appropriate actions can be taken in preventing further violation of linguistic human rights, but the initiative must also come from the speakers of endangered and minority languages. Only with mutual efforts will we be able to hope for a better future.

\section{References:}

David, C. (2000). Language Death. Cambridge: Cambridge University Press.

Department of Education. DepEd adds 7 more languages in mother tongue-based education. Retrieved January 13, 2016, from http://www.deped.gov.ph/pressreleases/deped-adds-7-more-languages-mother-tongue-based-education. 
Central Intelligence Agency. (2013). East \& Southeast Asia :: Philippines. The World Factbook 2013-14. Retrieved July 1, 2015, from https://www.cia.gov/library/publications/the-world-factbook/index.html.

Ethnic Groups of the Philippines. (2011). Table of languages. Retrieved July 1, 2015 from http://www.ethnicgroupsphilippines.com/people/table-of-languages/.

Fettes, M. (1997). Stabilizing What? An ecological approach to language renewal. In J. Reyhner (Ed.). Teaching Indigenous languages (pp. 301-318). Flagstaff, Arizona: Center for Excellence in Education.

Headland, T. N., \& Griffin, P. B. (1997). A Bibliography of the Agta Negritos of Eastern Luzon, Philippines (Vol. 4). SIL Electronic Working Papers.

Headland, T. N. (2003). Thirty endangered languages in the Philippines. Work Papers of the Summer Institute of Linguistics, University of North Dakota Session, 47, 1-12.

The Office of the President of the Philippines. (1987) The 1987 Constitution of the Republic of the Philippines, Article XIV, Section 7. Retrieved 1 July 2015 from http://www.gov.ph/.

Kroeber, A.M. (1963). Cultural and Natural Areas of Native North America. Berkley: Univ. Calif. Press.

Maffi, L. (2005). Linguistic, cultural and biological diversity. Annual Review of Anthropology, 34, 599-617

Magga, O. H. (1995, May). Rights for Indigenous Peoples. In Reinventing the Commons, "the fifth annual conference of the International Association for the Study of Common Property.

McCarty, T. L., Skutnabb-Kangas, T., \& Magga, O. H. (2008). Education for Speakers of Endangered Languages. In Spolsky, B., Francis, M., Hult et al. (Ed.) The handbook of educational linguistics (pp. 297-313). Oxford: Blackwell Publishing Ltd. National Statistics Office. (2014). The Philippines in figures. Manila, Philippines: National Statistic Office

Skutnabb Kangas, T. (2008). Human rights and language policy in education. In May, S., Hornberger, N. (Ed.) Encyclopedia of language and education (2nd ed.) (pp. 107120). New York: Springer.

\begin{abstract}
This paper deals with the relationship between culture and endangered languages, supporting attitudes about the necessity of preserving cultural, linguistic and biological diversity. The definitions of endangered languages and the specific relationship between dying languages, educational systems and possible solutions are presented in the first part of the paper. In the second part of the paper linguistic, cultural and biological diversity,
\end{abstract}


historical development of its research trends and current attitudes on this issue are discussed. The third part of the paper is about the Casiguran Agta language, one of the thirty endangered languages in the Philippines, as an example of how linguistic diversity loss is reflected in bio-cultural diversity loss. All the findings are based on existing theories and hypothesis; the danger of losing bio-cultural and linguistic diversity is pointed out in order to emphasize the importance of initiatives that should come from the speakers of endangered and minority languages.

Keywords: endangered languages, bio-cultural diversity, linguistic diversity, Casiguran Agta language.

\section{Biographical statement}

JOVANA LAZAREVIĆ graduated from the Faculty of Philology Department of English at the University of Belgrade in 2012 and completed her Master Program there in 2013. She enrolled in the first year of Doctoral studies at the Faculty of Philology-department of Culture in 2014 and is currently at the second year of her studies, working on her $\mathrm{PhD}$ thesis devoted to Serbian as a heritage language in Australia. Her main research interests are: educational linguistics, minority languages, and human linguistic rights.

E-mail: jovanalazarevic1@gmail.com 